\title{
Pengaruh Implementasi Kebijakan Penataan Pasar Tradisional Dan Toko Moden Terhadap Efektivitas Pembinaan Sektor Informal Di Kabupaten Subang
}

\author{
Ine Mariane ${ }^{1}$ \\ FISIP Universitas Pasundan Bandung \\ ine.mariane@unpas.ac.id
}

\section{Titin Kartini ${ }^{2}$}

Fakultas Ilmu Administrasi Universitas Subang

titin.unsub@gmail.com

\begin{abstract}
Abstrak
Hasil penelitian diatas hipotesis yang diajukan adalah : “terdapat pengaruh antara variabel implementasi kebijakan penataan pasar tradisional dan toko modern terhadap variabel efektivitas pembinaan sektor informal di Kabupaten Subang." Berdasarkan hasil pengujian dengan paket statistik programme for social science (SPSS) versi 16.0, diperoleh data besarnya pengaruh antara Implementasi kebijakan penataan pasar tradisional dan toko modern terhadap efektivitas pembinaan sektor informal di Kabupaten Subang adalah 0,888. Berdasarkan tabel koefisien korelasi tersebut termasuk dalam kategori "sangat kuat". Dari tabel coefficients diperoleh variabel Implementasi kebijakan dan Efektivitas nilai sig. Sebesar 0,000. Karena nilai probabilitas (sign) < nilai probabilitas 0,05, berdasarkan kriteria yang telah ditetapkan pada hipotesis maka dapat dibuktikan bahwa Implementasi kebijakan penataan pasar tradisional dan toko modern berpengaruh sangat kuat terhadap efektivitas pembinaan sektor informal di Kabupaten Subang.
\end{abstract}

Kata Kunci: Implementasi Kebijakan, Efektivitas

\section{Abstract}

Based on the results of the study note is: "there is influence between variable policy implementation arrangement of traditional markets and modern stores to variable effectiveness of coaching the informal sector in Subang." Based on the test results with statistical package program for social science (SPSS) version 16.0, was obtained the influence of data between the implementation of planning policies traditional markets and modern shops on the effectiveness of the informal sector guidance in Subang is 0.888. Based on the correlation coefficient table included in the category of "very strong". From the table variable coefficients obtained by the implementation of policies and Effectiveness sig. 0,000. Because the probability value (sign) < a probability value of 0.05 , based on the criteria established in the hypothesis it can be proved that the implementation of planning policies of traditional 
markets and modern stores very strong influence on the effectiveness of the informal sector guidance in Subang.

Keywords: Policy Implementation, Effectiveness

\section{Pendahuluan}

Perkembangan wilayah tergantung dari kegiatan sosial ekonomi penduduk suatu wilayah, yang kegiatan itu sendiri ditentukan oleh permintaan barang dan jasa. Sehingga kegiatan ekonomi erat kaitannya untuk mempertemukan permintaan dan penawaran, dan tempat kegiatannya dapat di jumpai dalam bentuk fisik yang disebut pasar dan tentu keaslian pasar ini bersifat tradisional dengan ciri-ciri sebagai berikut jual-beli barang kebutuhan primer dan sekunder, tempat usahanya berupa kios, warung, los, tenda, gerai, dan lapak, yang dimiliki/dikelola oleh pedagang kecil dengan skala kecil, modal yang kecil, dan dengan proses jual-beli barang dagangan melalui tawar menawar (Muhammad Aziz Hakim, 2005:98). Dengan semakin pesatnya perkembangan penduduk maka semakin besar pula tuntutan kebutuhan akan pasar baik secara kuantitas maupun kualitas. Seiring kemajuan teknologi dan manajemen maka berkembanglah pusat perbelanjaan, pusat perdagangan, department store, mall, hypermarket, supermarket. Hal ini mendorong pengelompokan kegiatan pada tempat-tempat tertentu. Dalam menetapkan kebijakan pembangunan sarana prasarana ekonomi, Pemerintah telah mengeluarkan PP No.112 tahun 2007 tentang Penataan dan Pembinaan Pasar Tradisional, Pusat Perbelanjaan dan Toko Modern. Serta Peraturan Daerah Kabupaten Subang No. 4 tahun 2010 tentang penataan pasar tradisional dan toko modern.

Sebagai penjabarannya dari aspek penataan ruang diperlukan jenis penetapan fungsi dan lokasi pasar tradisional dan toko modern yang memberikan arahan operasional atau petunjuk teknis mengenai pembangunan pasar tradisional dan toko modern yang sesuai rencana tata ruang wilayah dan rencana rinci tata ruang kawasan, peraturan zonasi, rencana tata bangunan dan lingkungan. Perkembangan pasar tradisional atau sektor informal semakin terdesak oleh perkembangan pasar modern dalam bentuk pusat-pusat perbelanjaan/perdagangan (hypermarket, supermarket, department store, mall, minimarket, dsb) baik yang melayani perkulakan, grosiran, maupun retail. Sektor usaha informal merupakan bentuk usaha yang paling banyak kita temukan di masyarakat. Sektor usaha informal terbuka bagi siapa saja dan sangat mudah mendirikannya, sehingga jumlahnya sulit di hitung, dengan banyaknya usaha ini berarti akan menyerap tenaga kerja dan mengurangi pengangguran. Dengan demikian sektor informal harus menjadi perhatian para perencana pembangunan dan tata kota terutama di negara-negara yang sedang berkembang.

Kebijakan Pemerintah dalam upaya pemberdayaan sektor informal agar dapat tumbuh dan berkembang serasi, saling membutuhkan/memerlukan, saling memperkuat dan simbiosis mutualistis, serta memberikan pedoman bagi penyelenggara pasar tradisional, pusat perbelanjaan, dan toko modern sehingga tercipta tertib persaingan dan keseimbangan. Persaingan diantara keduanya pun 
tidak terhindari. Tidak hanya itu, karena minimnya aturan zonasi dari pembangunan toko modern maka pasar tradisional yang berada kota-kota besar pun terkena imbasnya seperti di Kecamatan Subang. Persaingan akibat menjamurnya toko modern membawa dampak buruk terhadap keberadaan pasar tradisional. Salah satu dampak nyata dari kehadiran toko modern di tengah tengah pasar tradisional adalah turunnya pendapatan pedagang pasar setiap harinya. Globalisasi ekonomi juga berdampak pada masuknya investor asing maupun lokal (Luar Kabupaten Subang). Salah satu yang saat ini cukup marak dan tersebar di kabupaten Subang adalah berkembangnya pasar Modern (seperti Supermarket, Hypermarket) dan minimarket yang keberadaanya tidak dapat dicegah karena tuntutan globalisasi. Tidak dapat dipungkiri bahwa pasar modern dewasa ini sudah menjadi tuntutan dan konsekuensi dari gaya hidup modern yang berkembang di masyarakat. Tempat-tempat tersebut menjanjikan tempat belanja yang nyaman, bersih dengan harga yang tidak kalah menariknya. Berdasarkan penelitian mengenai implementasi kebijakan penataan pasar tradisional dan toko modern di kabupaten subang kurang optimal, dapat dideteksi dengan beberapa masalah sebagai berikut Kurang optimalnya pembinaan di pasar tradisional kecamtan sukamelang kabupaten subang; dan Semakin berkembangnya pertumbuhan toko modern di kabupaten subang toko.

\section{Kerangka Teori}

\section{Konsep Kebijakan Publik}

Sebagai landasan awal untuk menjelaskan konsep kebijakan publik, penulis akan menjelaskan secara teoritik pengertian kebijakan, pengertian kebijakan publik, pengertian implementasi kebijakan, perspektif teoritik, tahap - tahap kebijakan publik dan faktor - faktor yang mempengaruhi implementasi kebijakan publik. Sebelum dibahas lebih jauh mengenai konsep kebijakan publik, kita perlu mengakaji terlebih dahulu mengenai konsep kebijakan atau dalam bahasa inggris sering kita dengar dengan istilah policy. Dalam Kamus Besar Bahasa Indonesia, kebijakan diartikan sebagai rangkaian konsep dan asas yang menjadi garis besar dan dasar rencana dalam pelaksanaan suatu pekerjaan, kepemimpinan, dan cara bertindak (tentang pemerintahan, organisasi, dsb); pernyataan cita-cita, tujuan, prinsip dan garis pedoman untuk manajemen dalam usaha mencapai sasaran. Carl J Federick sebagaimana dikutip Leo Agustino (2008:7) mendefinisikan kebijakan sebagai serangkaian tindakan/kegiatan yang diusulkan seseorang, kelompok atau pemerintah dalam suatu lingkungan tertentu dimana terdapat hambatan-hambatan (kesulitan-kesulitan) dan kesempatan-kesempatan terhadap pelaksanaan usulan kebijaksanaan tersebut dalam rangka mencapai tujuan tertentu. Pendapat ini juga menunjukan bahwa ide kebijakan melibatkan perilaku yang memiliki maksud dan tujuan merupakan bagian yang penting dari definisi kebijakan, karena bagaimanapun kebijakan harus menunjukan apa yang sesungguhnya dikerjakan daripada apa yang diusulkan dalam beberapa kegiatan pada suatu masalah. Solichin Abdul Wahab mengemukakan bahwa istilah kebijakan sendiri masih terjadi silang pendapat dan merupakan ajang perdebatan para ahli. Maka untuk memahami 
istilah kebijakan, Solichin Abdul Wahab (2008: 40-50) memberikan beberapa pedoman sebagai berikut:

1) Kebijakan harus dibedakan dari keputusan

2) Kebijakan sebenarnya tidak serta merta dapat dibedakan dari administrasi

3) Kebijakan mencakup perilaku dan harapan-harapan

4) Kebijakan mencakup ketiadaan tindakan ataupun adanya tindakan

5) Kebijakan biasanya mempunyai hasil akhir yang akan dicapai

6) Kebijakan biasanya mempunyai hasil akhir yang akan dicapai

7) Kebijakan biasanya mempunyai hasil akhir yang akan dicapai

8) Setiap kebijakan memiliki tujuan atau sasaran tertentu baik eksplisit maupun implicit

9) Kebijakan muncul dari suatu proses yang berlangsung sepanjang waktu

10) Kebijakan meliputi hubungan-hubungan yang bersifat antar organisasi dan yang bersifat intra organisasi

11) Kebijakan publik meski tidak ekslusif menyangkut peran kunci lembagalembaga pemerintah

12) Kebijakan itu dirumuskan atau didefinisikan secara subyektif

Menurut Budi Winarno (2007 : 15), istilah kebijakan (policy term) mungkin digunakan secara luas seperti pada "kebijakan luar negeri Indonesia” , "kebijakan ekonomi Jepang", dan atau mungkin juga dipakai untuk menjadi sesuatu yang lebih khusus, seperti misalnya jika kita mengatakan kebijakan pemerintah tentang debirokartisasi dan deregulasi. Namun baik Solihin Abdul Wahab maupun Budi Winarno sepakat bahwa istilah kebijakan ini penggunaanya sering dipertukarkan dengan istilah lain seperti tujuan (goals) program, keputusan, undang-undang, ketentuan-ketentuan, standar, proposal dan grand design (Suharno :2009:11). Irfan Islamy sebagaimana dikutip Suandi (2010: 12) kebijakan harus dibedakan dengan kebijaksanaan. Policy diterjemahkan dengan kebijakan yang berbeda artinya dengan wisdom yang artinya kebijaksanaan. Pengertian kebijaksanaan memerlukan pertimbangan pertimbangan lebih jauh lagi, sedangkan kebijakan mencakup aturan - aturan yang ada didalamnya. James E Anderson sebagaimana dikutip Islamy (2009: 17) mengungkapkan bahwa kebijakan adalah " a purposivecourse of action followed by an actor or set of actors in dealing with aproblem or matter of concern" (Serangkaian tindakan yang mempunyai tujuan tertentu yang diikuti dan dilaksanakan oleh seorang pelaku atau sekelompok pelaku guna memecahkan suatu masalah tertentu).

Konsep kebijakan yang ditawarkan oleh Anderson ini menurut Budi Winarno (2007: 18) dianggap lebih tepat karena memusatkan perhatian pada apa yang sebenarnya dilakukan dan bukan pada apa yang diusulkan atau dimaksudkan. Selain itu konsep ini juga membedakan secara tegas antara kebijakan (policy) dengan keputusan (decision) yang mengandung arti pemilihan diantara berbagai alternatif yang ada. Richard Rose sebagaimana dikutip Budi Winarno (2007: 17) juga menyarankan bahwa kebijakan hendaknya dipahami sebagai serangkaian kegiatan yang sedikit banyak berhubungan beserta konsekuensi-konsekuensi bagi mereka yang bersangkutan daripada sebagai keputusan yang berdiri sendiri.Pendapat kedua ahli tersebut setidaknya dapat menjelaskan bahwa mempertukarkan istilah kebijakan dengan keputusan adalah keliru, karena pada dasarnya kebijakan 
dipahami sebagai arah atau pola kegiatan dan bukan sekadar suatu keputusan untuk melakukansesuatu. Berdasarkan pendapat berbagai ahli tersebut di atas maka dapat disimpulkan bahwa kebijakan adalah tindakan-tindakan atau kegiatan yang sengaja dilakukan atau tidak dilakukan oleh seseorang, suatu kelompok atau pemerintah yang di dalamnya terdapat unsur keputusan berupa upaya pemilihan diantara berbagai alternatif yang ada guna mencapai maksud dan tujuan tertentu.

Lingkup dari studi kebijakan publik sangat luas karena mencakup berbagai bidang dan sektor seperti ekonomi, politik, sosial, budaya, hukum, dan sebagainya. Disamping itu dilihat dari hirarkirnya kebijakan publik dapat bersifat nasional, regional maupun lokal seperti undang - undang, peraturan pemerintah, peraturan presiden, peraturan menteri, peraturan pemerintah daerah/provinsi, keputusan gubernur, peraturan daerah kabupaten/kota,dan keputusan bupati/walikota. Secara terminologi pengertian kebijakan publik (public policy) itu ternyata banyak sekali, tergantung dari sudut mana kita mengartikannya.Easton memberikan definisi kebijakan publik sebagai the authoritativeallocation of values for the whole society atau sebagai pengalokasian nilai - nilai secara paksa kepada seluruh anggota masyarakat. Laswell dan Kaplan juga mengartikan kebijakan publik sebagai $a$ projected program of goal,value, and practice atau sesuatu program pencapaian tujuan, nilai-nilai dalam praktek-praktek yang terarah. Pressman dan Widavsky sebagaimana dikutip Budi Winarno (2002: 17) mendefinisikan kebijakan publik sebagai hipotesis yang mengandung kondisi-kondisi awal dan akibat-akibat yang bias diramalkan. Kebijakan publik itu harus dibedakan dengan bentuk-bentuk kebijakan yang lain misalnya kebijakan swasta. Hal ini dipengaruhi oleh keterlibatan faktor-faktor bukan pemerintah. Robert Eyestone sebagaimana dikutip Leo Agustino (2008 : 6) mendefinisikan kebijakan publik sebagai "hubungan antara unit pemerintah dengan lingkungannya". Banyak pihak beranggapan bahwa definisi tersebut masih terlalu luas untuk dipahami, karena apa yang dimaksud dengan kebijakan publik dapat mencakup banyak hal. Menurut Nugroho, ada dua karakteristik dari kebijakan publik, yaitu:1) kebijakan publik merupakan sesuatu yang mudah untuk dipahami, karena maknanya adalah hal-hal yang dikerjakan untuk mencapai tujuan nasional; 2) kebijakan publik merupakan sesuatu yang mudah diukur, karena ukurannya jelas yakni sejauh mana kemajuan pencapaian cita-cita sudah ditempuh. Menurut Woll sebagaimana dikutip Tangkilisan (2003:2) menyebutkan bahwa kebijakan publik ialah sejumlah aktivitas pemerintah untuk memecahkan masalah di masyarakat, baik secara langsung maupun melalui berbagai lembaga yang mempengaruhi kehidupan masyarakat. Thomas $\mathrm{R}$ Dye sebagaimana dikutip Islamy (2009: 19) mendefinisikan kebijakan publik sebagai " is whatever government chooseto do or not to do" ( apapaun yang dipilih pemerintah untuk dilakukan atau untuk tidak dilakukan). Definisi ini menekankan bahwa kebijakan publik adalah mengenai perwujudan "tindakan" dan bukan merupakan pernyataan keinginan pemerintah atau pejabat publik semata. Di samping itu pilihan pemerintah untuk tidak melakukan sesuatu juga merupakan kebijakan publik karena mempunyai pengaruh (dampak yang sama dengan pilihan pemerintah untuk melakukan sesuatu. Terdapat beberapa ahli yang mendefiniskan kebijakan public sebagai tindakan yang diambil oleh pemerintah dalam merespon suatu krisis atau masalah publik. Berdasarkan pendapat berbagai ahli tersebut dapat 
disimpulkan bahwa kebijakan publik adalah serangkaian tindakan yang dilakukan atau tidak dilakukan oleh pemerintah yang berorientasi pada tujuan tertentu guna memecahkan masalah-masalah publik atau demi kepentingan publik. Kebijakan untuk melakukan sesuatu biasanya tertuang dalam ketentuan - ketentuan atau peraturan perundang-undangan yang dibuat pemerintah sehingga memiliki sifat yang mengikat dan memaksa.

\section{Implementasi Kebijakan Publik}

Pressman dan Wildavsky (dalam Tachjan,2008:29) mengemukakan bahwa, implementation as to carry out, accomplish fulfill produce, complete". Maksudnya adalah membawa, menyelesaikan, mengisi, menghasilkan, melengkapi. Jadi secara etimologis implementasi itu dapat dimaksudkan sebagai suatu aktivitas yang berkaitan dengan penyelesaian suatu pekerjaan dengan penggunaan sarana untuk memperoleh hasil. Apabila pengertian implementasi di atas dirangkaikan dengan kebijakan publik, maka kata implementasi kebijakan publik dapat diartikan sebagai aktivitas penyelesaian atau pelaksanaan suatu kebijakan publik yang telah ditetapkan/disetujui dengan penggunaan sarana untuk mencapai tujuan kebijakan. Implementasi kebijakan adalah proses pelaksanaan keputusan kebijakan yang dibuat oleh lembaga pemerintah yang diarahkan untuk mencapai tujuan yang ditetapkan dalam keputusan kebijakan tersebut. Proses playanan kebijakan dimulai apabila tujuan-tujuan kebijakan telah ditetapkan, terbentuknya program pelaksanaan. Anderson (1975) menyebutkan 4 (empat) aspek penting dalam implementasi, hakekat proses administrasi, kepatuan atas suatu efek atau dampak implement. Implementasi kebijakan dalam pemerintah yang luas, merupakan alat administrasi hukum dimana berbagai aktor, organisasi, prosedur, dan teknik bekerja bersama-sama untuk menjalankan kebijakan guna meraih dampak atau tujuan yang diinginkan. Implementasi dari sisilain merupakan fenomena yang kompleks, mungkin dapat dipahami sebagai proses, keluaran (out put) maupun sebagai hasil. Sementara itu menurut pendapat Van Mater dan Van Horen dalam Winarno (2005), proses implementasi sebagai "those actions by public or private individuals (or groups) that are directed at the achievement of objectives set forthe in prior decisions" (tindakantindakan yang dilakukan baik oleh individu-individu/pejabat-pejabat/ kelompok kelompok pemerintah atau swasta yang diarahkan pada tercapainya tujuan -tujuan yang telah digariskan dalam keputusan kebijaksanaan ), grindle dalam abdul Wahab (2005), implementasi kebijakan (policy implementation) merupakan aspek penting dari keseluruhan proses kebijakan. Implementasi bukanlah sekedar bersangkut paut dengan mekanisme penjabaran keputusan - keputusan politik kedalam prosedurprosedur rutin lewat saran-saran birokrasi, melalui lebih dari itu, termasuk masalah konflik, keputusan dan siapa yang memperoleh apa dari suatu kebijakan. Pelaksanaan kebijakan adalah sesuatu yang penting, bahkan mungkin jau lebih penting dari pada pembuatan kebijakan. Kebijakan-kebijakan akan sekedar berupa impian atau rencana bagus yang tersimpan rapi dalam arsip kalau tidak diimplementasikan. Fungsi implementasi kebijakan menurut Abdul Wahab (1997) adalah untuk membentuk suatu hubungan yang memungkinkan tujuan-tujuan atau sasaran kebijakan negara diwujudkan sebagai suatu outcome (hasil). Sayangnya, dalam khasanah pengetahuan yang kini dikenal dengan sebutan ilmu kebijakan 
publik, harus diakui bahwa hanya baru pada dasar terakhir ini saja para ilmuwan sosial, khususnya pada para ahli ilmu politik menaruh perhatian yang besar terhadap masalah persoalan pelaksanaan kebijakan atau menerimanya sebagai bagian integral dari studi proses perumusan kebijakan. Proses untuk melakukan kebujakan perlu mendapatkan perhatian yang seksama. Karna itu, keliru apabila menganggap bahwa proses pelaksanaan kebijakan dengan sendirinya akan berlangsung secara mulus tanpa hambatan. Harus di pahami bahwa proses kebijakan merupakan proses dinamis, banyak faktor yang mempengaruhinya. Kebijakan yang telah ditetapkan oleh pemerintah dan memperoleh legitimasi dari lembaga legislatif telah memungkinkan birokrasi untuk bertindak. Pelaksanaan kebijakan dirumuskan secara pendek to implement (untuk pelaksanaan) berarti to provide the means fof carrying out (menyediakan sarana untuk melaksanakan sesuatu), berarti to give practical effect to (menimbulkan dampak pada sesuatu ). Kalau pandangan ini diikuti, maka pelaksanaan kebijakan dapat dipandang sebagai suatu proses melaksanakan keputusan kebijakan, biasanya dalam bentuk undang-undang peraturan pemerintah, peraturan daerah, keputusan peradilan, perintah eksekutif, atau dekrit presiden. Dengan demikian dapat disimpulkan bahwa proses implementasi kebijakan itu sesunguhnya tidak hanya menyangkut prilaku badanbadan atministratif yang bertanggungjawab untuk melaksanakan program dan menimbulkan ketaatan pada diri kelompok sasaran, melainkan pula menyangkut jaringan kekuatan-kekuatan politi, ekonomi, dan sosial yang langsung atau tidak langsung dapat mempengaruhi prilaku dari semua pihak yang terlibat, dan yang pada akhinya berpengaruh terhadap dampak baik yang diharap (intended) maupun yangtidak diharapkan. Untuk mengefektifkan kebijakan yang ditetapkan maka diperlukan adanya sifat implementasi kebijakan menurut Islami (1997-102-106). Sifat kebijakan di bedakan menjadi 2 (dua) bentuk yaitu:

1) Bersifat Self Executing yang berarti bahwa dengan dirumuskannya dan disahkanya suatu kebijakan maka kebijakan tersebut akan terimplementasikan dengan sendirinya, misalnya pengakuan suatu negara terhadap kedaulatan negara lain.

2) Bersifat Non Self Executing bahwa suatu kebijakan publik perlu diwujudkan dan dilaksanakan oleh berbagai pihak supaya tujuan pembuatan kebijakan tercapai.

\section{Tahap- Tahap Kebijakan Publik}

Proses pembuatan kebijakan publik merupakan proses yang kompleks karena melibatkan banyak proses maupun variabel yang harus dikaji. Oleh karena itu beberapa ahli politik yang menaruh minat untuk mengkaji kebijakan publik membagi proses-proses penyusunan kebijakan publik kedalam beberapa tahap.Tujuan pembagian seperti ini adalah untuk memudahkan kita dalam mengkaji kebijakan publik. Namun demikian, beberapa ahli mungkin membagi tahap-tahap ini dengan urutan yang berbeda. Tahap-tahap kebijakan publik menurut William Dunn sebagaimana dikutip Budi Winarno (2007: 32-34 adalah sebagai berikut :

1) Tahap penyusunan agenda 
Para pejabat yang dipilih dan diangkat menempatkan masalah pada agenda publik.Sebelumnya masalah ini berkompetisi terlebih dahulu untuk dapat masuk dalam agenda kebijakan.Pada akhirnya, beberapa masalah masuk ke agenda kebijakan para perumus kabijakan. Pada tahap ini mungkin suatu masalah tidak disentuh sama sekali, sementara masalah yang lain ditetapkan menjadi focus pembahasan, atau ada pula masalah karena alasanalasan tertentu ditunda untuk waktu yang lama.

2) Tahap formulasi

kebijakan masalah yang telah masuk ke agenda kebijakan kemudian dibahas oleh para pembuat kebijakan.Masalah-masalah tadi didefinisikan untuk kemudian dicari pemecahan masalah terbaik. Pemecahan masalah tersebut berasal dari berbagai alternatif atau pilihan kebijakan (policy alternatives/policy options) yang ada.Dalam perumusan kebijakan masingmasing alternatif bersaing untuk dapat dipilih sebagai kebijakan yang diambil untuk memecahkan masalah. Dalam tahap ini masing-masing actor akan bersaing dan berusaha untuk mengusulkan pemecahan masalah terbaik.

3) Tahap adopsi kebijakan

Dari sekian banyak alternatif kebijakan yang ditawarkan oleh para perumus kebijakan, pada akhirnya salah satu dari alternative kebijakan tersebut diadopsi dengan dukungan dari mayoritas legislatif, konsensus antara direktur lembaga atau putusan peradilan.

4) Tahap Implementasi Kebijakan

Suatu program kebijakan hanya akan menjadi catatan-catatan elit jika program tersebut tidak diimplementasikan, yakni dilaksanakan oleh badanbadan administrasi maupun agen-agen pemerintah di tingkat bawah. Kebijakan yang telah diambil dilaksanakan oleh unit-unit administrasikan yang memobilisasikan sumber daya finansial dan manusia. Pada tahap implementasi ini berbagai kepentingan akan saling bersaing. Beberapa implementasi kebijakan mendapat dukungan para pelaksana (implementors), namun beberapa yang lain munkin akan ditentang oleh para pelaksana.

5) Tahap evaluasi kebijakan

Dalam tahap ini kebijakan yang telah dijalankan akan dinilai atau dievaluasi, unuk melihat sejauh mana kebijakan yang dibuat untuk meraih dampak yang diinginkan, yaitu memecahkan masalah yang dihadapi masyarakat. Oleh karena itu ditentukan ukuran-ukuran atau kriteria kriteria yang menjadi dasar untuk menilai apakah kebijakan publik yang telah dilaksanakan sudah mencapai dampak atau tujuan yang diinginkan atau belum.

\section{Faktor- factor Yang Mempengaruhi Kebijakan Publik}

Edward III (1980-28) menyebutkan 4 (empat) faktor yang mempengaruihi implementasi, yaitu:

1) Communication transmition, clarify and consistency (terjadi proses komunikasih yang disampaikan dengan jelas dan konsisten)

2) Resources: staff, infirmation, outhority,fasilities (terdapat sumberdaya yang didukung oleh setaf, informasi, kewenangan maupun fasilitas yang memadai) 
3) Disposition:incentives,staffing (terdapat pertunjukan yang jelas mengenaipemberian insentif dan dukungan staf)

4) Bureauceratic Structure; standard operating procedures, fragmentation (terdapat sistem birokrasi yang memiliki prosedur standar kerja yang memadai).

\section{Teori Efektivitas}

Sebagai landasan awal untuk menjelaskan teori efektivitas, penulis akan menjelaskan secara teoritik dari pengertian efektivitas, factor- factor yang mempengaruhi efektivitas dan pengukuran efektivitas. Efektivitas atau dalam bahasa Inggris "effectiveness" berarti keberhasilan atau sesuatu yang ada pengaruhnya. Ensiklopedi Administrasi, pengertian efektivitas adalah suatu keadaan yang mengandung pengertian mengenai terjadinya sesuatu efek atau akibat yang dikehendaki, kalau seseorang melakukan sesuatu perbuatan dengan maksud tertentu yang memang dikehendaki, maka orang itu dikatakan efektif kalau menimbulkan akibat atau mempunyai maksud sebagaimana yang dikehendakinya. H. Emerson (dalam Handayaningrat,1995:16), menyatakan bahwa Efektivitas merupakan pengukuran dalam arti tercapainya sasaran atau tujuan yang telah ditentukan sebelumnya. Jadi kalau tujuan atau sasaran itu tidak selesai, pekerjaan itu tidak efektif. Atau tercapainya tujuan itu adalah efektif sebab mempunyai efek atau pengaruh yang benar terhadap kepentingan masyarakat banyak. Michael E. Mc. Gill (1992: 7) menyatakan efektivitas merupakan suatu tingkat prestasi organisasi dalam mencapai tujuan, artinya sejauhmana tujuan yang telah ditetapkan dapat tercapai. Berdasarkan beberapa pendapat tersebut maka secara substansi, dapat dijelaskan bahwa efektivitas merupakan dampak hasil kinerja dari kegiatan manajemen publik. Selanjutnya Nugroho (2003: 179), mengemukakan bahwa Efektivitas implementasi kebijakan mencakup empat tempat yaitu tepat kebijakannya, tepat pelaksanaannya, tepat targetnya dan tepat lingkungannya. Implementasi kebijakan dinyatakan efektif jika prosesnya dilaksanakan secara normatif dan hasilnya mencerminkan tujuan yang dikehendaki. Dengan penjelasan di atas maka dapat disimpulkan bahwa efektivitas merupakan dampak dari serangkaian proses untuk mengukur pencapaian dari tujuan atau sasaran yang telah di tetapkan.

\section{Faktor- faktor Yang Mempengaruhi Efektivitas}

Kemudian, empat faktor yang mempengaruhi efektivitas, yang dikemukakan oleh Richard M Steers (1985:8) peneliti uraikan sebagai berikut :

1) Karakteristik Organisasi adalah hubungan yang sifatnya relatif tetap seperti susunan sumber daya manusia yang terdapat dalam organisasi. Struktur merupakan cara yang unik menempatkan manusia dalam rangka menciptakan sebuah organisasi. Dalam struktur, manusia ditempatkan sebagai bagian dari suatu hubungan yang relatif tetap yang akan menentukan pola interaksi dan tingkah laku yang berorientasi pada tugas.

2) Karakteristik Lingkungan mencakup dua aspek. Aspek pertama adalah lingkungan ekstern yaitu lingkungan yang berada di luar batas organisasi dan sangat berpengaruh terhadap organisasi, terutama dalam pembuatan keputusan dan pengambilan tindakan. Aspek kedua adalah lingkungan intern 
yang dikenal sebagai iklim organisasi yaitu lingkungan yang secara keseluruhan dalam lingkungan organisasi.

3) Karakteristik Pekerja merupakan faktor yang paling berpengaruh terhadap efektivitas. Di dalam diri setiap individu akan ditemukan banyak perbedaan, akan tetapi kesadaran individu akan perbedaan itu sangat penting dalam upaya mencapai tujuan organisasi. Jadi apabila suatu organisasi menginginkan keberhasilan, organisasi tersebut harus dapat mengintegrasikan tujuan individu dengan tujuan organisasi.

4) Karakteristik Manajemen adalah strategi dan mekanisme kerja yang dirancang untuk mengkondisikan semua hal yang ada di dalam organisasi sehingga efektivitas tercapai. Kebijakan dan praktek manajemen merupakan alat bagi pimpinan untuk mengarahkan setiap kegiatan guna mencapai tujuan organisasi. Dalam melaksanakan kebijakan dan praktek manajemen harus memperhatikan manusia, tidak hanya mementingkan strategi dan mekanisme kerja saja. Mekanisme ini meliputi penyusunan tujuan strategis, pencarian dan pemanfaatan atas sumber daya, penciptaan lingkungan prestasi, proses komunikasi, kepemimpinan dan pengambilan keputusan, serta adaptasi terhadap perubahan lingkungan inovasi organisasi

Menurut pendapat tersebut di atas penulis kemudian mengambil kesimpulan bahwa :

1) Organisasi terdiri atas berbagai unsur yang saling berkaitan, jika salah satu unsur memiliki kinerja yang buruk, maka akan mempengaruhi kinerja organisasi secara keseluruhan.

2) Keefektifan membutuhkan kesadaran dan interaksi yang baik dengan lingkungan.

3) Kelangsungan hidup organisasi membutuhkan pergantian sumber daya secara terus menerus. Suatu perusahaan yang tidak memperhatikan faktor-faktor yang mempengaruhi efektivitas organisasi akan mengalami kesulitan dalam mencapai tujuannya, tetapi apabila suatu perusahaan memperhatikan faktorfaktor tersebut maka tujuan yang ingin dicapai dapat lebih mudah tercapai hal itu dikarenakan efektivitas akan selalu dipengaruhi oleh faktor-faktor tersebut.

Gibson (1997:34) menguraikan bahwa kasus mengenai kriteria efektivitas sama halnya dengan menguraikan kejadian yang akan datang, dimana tidak dapat dipastikan secara pasti. Bahwa ukuran produktivitas, efisiensi dan kepuasan telah nyata, lebih mudah diperiksa dan lebih obyektif dalam pengukuran efektifnya suatu organisasi dari pada ukuran mengenai kemampuan menyesuaikan diri dan pengembangan. Proses pengukuran kriteria efektivitas organisasi dalam kaitannya dengan organisasi biasanya sering menggunakan sasaran produk atau yang dikenal sebagai produktivitas. Secara umum produktivias diartikan sebagai hubungan hasil yang nyata maupun fisik (barang/jasa) dengan masukan sebenarnya. Sumber daya masukan (input) terdiri dari faktor-faktor produksi seperti tanah, gedung, mesin, peralatan, bahan mentah merupakan sasaran strategis karena peningkatan produktivitas faktor faktor lainnya tergantung pada kemampuan tenaga manusia memanfaatkannya.

\section{Metode Penelitian}


Penelitian ini menggunakan pendekatan kuantitatif, dengan jenis penelitian deskriptif dan asosiatif korelasional. Menurut Nasir (2011 : 54) metode deskriptif adalah suatu metode dalam meneliti status sekelompok manusia, suatu objek, suatu set kondisi, suatu sistem pemikiran, ataupun suatu kelas peristiwa pada masa sekarang. Tujuan dari penelitian deskriptif ini adalah untuk membuat deskripsi, gambaran atau lukisan secara sistematis, factual dan akurat mengenai fakta-fakta, sifat-sifat serta hubungan antarfenomena yang diselidiki. Melalui ini data-data dikumpulkan dari sumber data primer dan sekunder di mana data primer diperoleh dari menyebarkan koesioner kepada responden untuk memperoleh fakta yang relevan dan up to date yang dilakukan di lapangan.

\section{Hasil dan Pembahasan}

\section{Pengujian Reliabilitas Instrumen}

Uji reliabilitas menggunakan metode konsistensi antar butir yakni dengan rumus Cronbach.

Tabel 1

Hasil Pengujian Reliabilitas Variabel Implementasi Kebijakan

Reliability Statistics
\begin{tabular}{|r|r|}
\hline $\begin{array}{c}\text { Cronbach's } \\
\text { Alpha }\end{array}$ & $\begin{array}{c}\text { N of } \\
\text { Items }\end{array}$ \\
\hline .733 & 11 \\
\hline
\end{tabular}

Berdasarkan hasil pengujian dengan spss versi 16.0, untuk variabel Implementasi Kebijakan dari hasil uji reliabilitas pada variabel, didapatkan nilai Cronbach untuk variabel Implementasi Kebijakan adalah 0,733 digolongkan reliabilitas yang baik dan digolongkan reliabilitas yang dapat diterima, karena hasil uji reliabilitas variabel tersebut diatas 0,6 maka uji reliabilitas dinyatakan "reliabel". Dengan demikian instrumen penelitian ini selanjutnya sudah layak digunakan untuk menghimpun data (untuk hasil pengujian dapat dilihat pada lampiran).

Tabel 2

\section{Hasil Pengujian Reliabilitas Variabel Efektivitas}

\section{Reliability Statistics}

\begin{tabular}{|r|r|r|}
\hline & $\begin{array}{r}\text { Cronbach's } \\
\text { Alpha } \\
\text { Based on } \\
\text { Standard } \\
\text { ized }\end{array}$ & \\
Cronbach's & N of \\
Alpha & Items & Items \\
\hline .775 & .784 & 9 \\
\hline
\end{tabular}


Berdasarkan hasil pengujian dengan spss versi 16.0, untuk variabel Efektivitas dari hasil uji reliabilitas pada variabel, didapatkan nilai Cronbach untuk variabel Efektivitas adalah 0.775 yang baik dan dapat digolongkan reliabilitas yang dapat diterima, karena hasil uji reliabilitas variabel tersebut diatas 0,6 maka uji reliabilitas dinyatakan "reliabel". Dengan demikian instrumen penelitian ini selanjutnya sudah layak digunakan untuk menghimpun data (untuk hasil pengujian dapat dilihat pada lampiran).

\section{Tanggapan Responden atas Variabel Implementasi Kebijakan}

Penulis mengukur sejauh mana Implementasi di lingkup Kantor Dinas Perindustrian, Perdagangan dan Pengelolaan Pasar Kabupaten Subang mengacu pada pendapat Edward III (1980-28) menyebutkan 4 (empat) faktor yang mempengaruihi implementasi, yaitu:

1) Communication transmition, clarify and consistency (terjadi proses komunikasi yang disampaikan dengan jelas dan konsisten).

2) Resources: staff, infirmation, outhority,fasilities (terdapat sumberdaya yang didukung oleh setaf, informasi, kewenangan maupun fasilitas yang memadai).

3) Disposition:incentives,staffing (terdapat pertunjukan yang jelas mengenaipemberian insentif dan dukungan staf).

4) Bureauceratic Structure; standard operating procedures, fragmentation (terdapat sistem birokrasi yang memiliki prosedur standar kerja yang memadai).

Dari hasil penelitian di atas jawaban kuesioner yang telah dijawab responden, berikut penulis sajikan persentase tanggapan responden atas implementasi kebijakan pada Dinas Perindustrian, Perdagangan dan Pengelolaan Pasar Kabupaten Subang adalah sebagai berikut :

\section{Tanggapan Responden atas Dimensi Komunikasi}

Untuk mengetahui tanggapan responden atas dimensi komunikasi, yang kemudian hasilnya ditabulasikan dalam bentuk pie chart yang dijelaskan sebagai berikut :

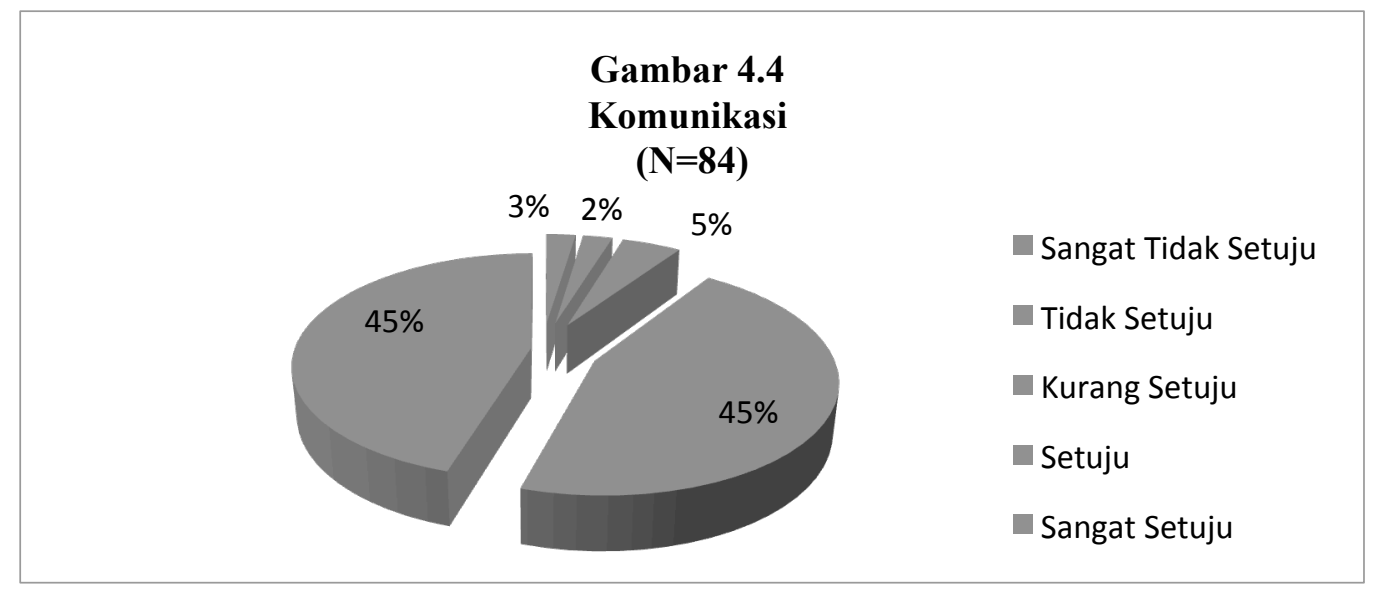

Sumber : Hasil Penelitian 
Dari data yang dikumpulkan tentang komunikasi, responden memilih sangat setuju dan responden memilih setuju lebih dominan. Hal ini dapat ditafsirkan bahwa, Responden berpendapat bahwa komunikasi dari pegawai Dinas Perindustrian, Perdagangan dan Pengelolaan Pasar pada bidang pengelolaan pasar dalam melaksanakan pekerjaannya bisa dikategorikan sudah cukup baik meskipun belum maksimal secara keseluruhan karena masih ada responden yang memilih kurang setuju, tidak setuju, dan sangat tidak setuju meskipun dalam jumlah yang sedikit, sehingga peneliti berpendapat bahwa komunikasi pegawai dalam melaksanakan pekerjaannya belum maksimal secara keseluruhan.

\section{Tanggapan Responden atas Dimensi Sumber Daya}

Untuk mengetahui tanggapan responden atas Dimensi Sumberdaya, yang kemudian hasilnya ditabulasikan dalam bentuk pie chart yang dijelaskan sebagai berikut :

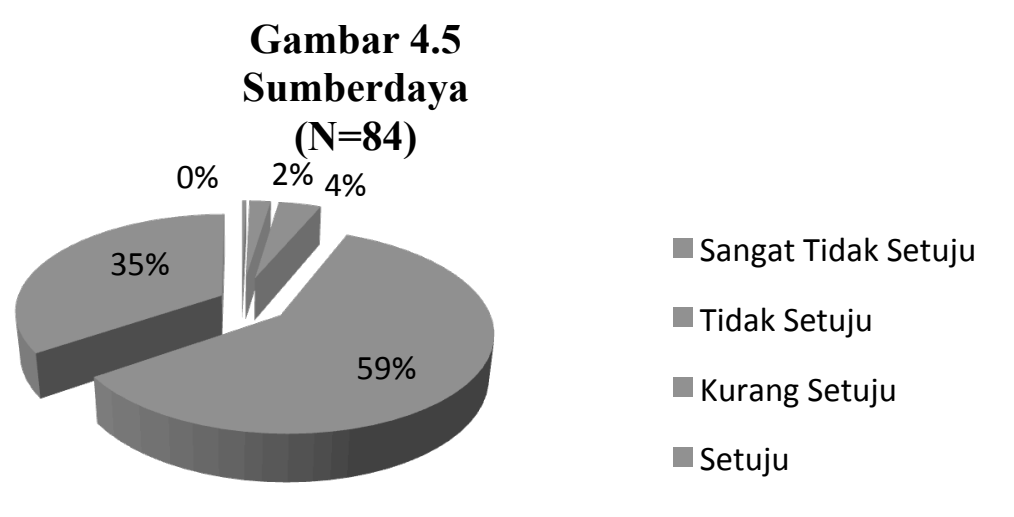

Sumber : Hasil Penelitian,

Dari data yang dikumpulkan tentang sumberdaya, responden yang memilih setuju lebih domiinan dan responden yang memilih sangat setuju menjadi pilihan yang paling dominan kedua. Hal ini dapat ditafsirkan bahwa, responden berpendapat bahwa sumberdaya dari pegawai Dinas Perindustrian, Perdagangan dan Pengelolaan Pasar pada bidang pengelolaan pasar dalam melaksanakan pekerjaannya bisa dikategorikan sudah cukup baik dalam melaksanakan tugasnya, meskipun belum maksimal secara keseluruhan karena masih ada responden yang memilih kurang setuju, dan tidak setuju, meskipun dalam jumlah responden yang sedikit, sehingga peneliti berpendapat bahwa sumberdaya pegawai dalam melaksanakan pekerjaannya masih belum maksimal secara keseluruhan.

\section{Tanggapan Responden atas Dimensi Disposisi}

Untuk mengetahui tanggapan responden atas Dimensi Disposisi, yang kemudian hasilnya ditabulasikan dalam bentuk pie chart yang dijelaskan sebagai berikut : 


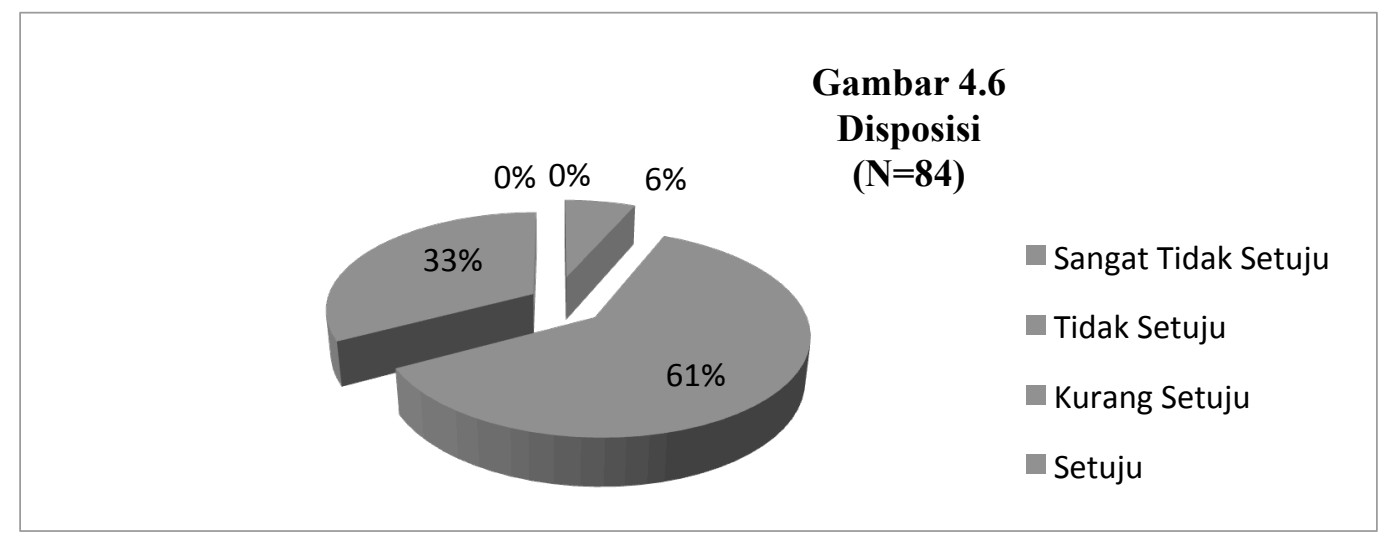

Dari data yang dikumpulkan tentang disposisi, responden memilih sangat setuju dan responden memilih setuju lebih dominan tetapi yang paling dominan responden yang memilih setuju. Hal ini dapat ditafsirkan bahwa, responden berpendapat bahwa disposisi dari Dinas Perindustrian, Perdagangan dan Pengelolaan Pasar pada bidang pengelolaan pasar dalam melaksanakan pekerjaannya bisa dikategorikan sudah cukup baik meskipun belum maksimal secara keseluruhan karena masih ada responden yang memilih kurang setuju, meskipun dalam jumlah responden yang sedikit, sehingga peneliti berpendapat bahwa disposisi yang ada belum maksimal secara keseluruhan.

\section{Tanggapan Responden atas Dimensi Struktur Birokrasi}

Untuk mengetahui tanggapan responden atas Dimensi Struktur Birokrasi, yang kemudian hasilnya ditabulasikan dalam bentuk pie chart yang dijelaskan sebagai berikut :

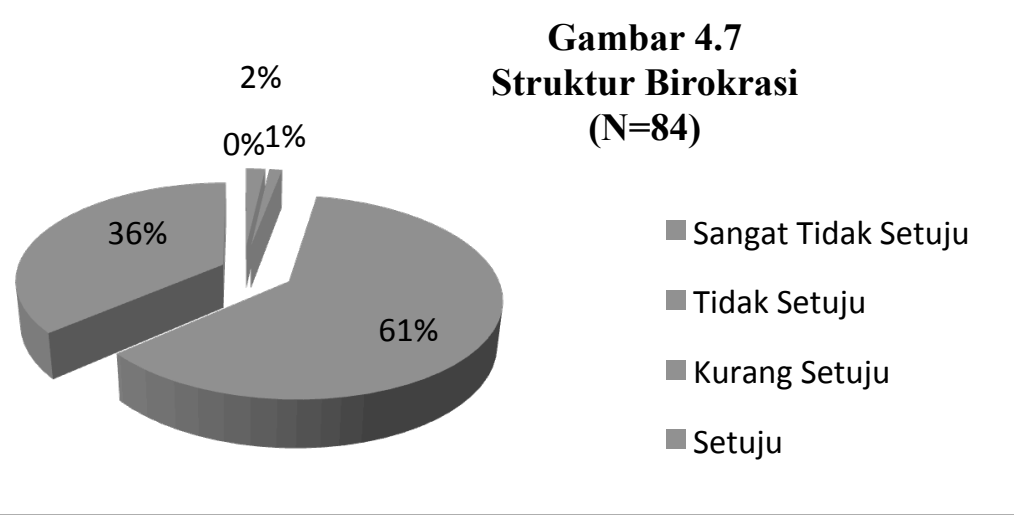

Sumber : Hasil Penelitian, 2016

Struktur Birokrasi sangat berpengaruh terhadap pekerjaan yang dikerjakannya, karena semakin baik struktur birokrasinya maka akan semakin handal dan dapat dikategorikan berkompeten atau memiliki kompetensi. Dari hasil perhitungan yang penulis lakukan terhadap hasil tanggapan responden pada dimensi struktur birokrasi dapat disimpulkan bahwa secara umum struktur birokrasi di Dinas Perindustrian, Perdagangan dan Pengelolaan Pasar Kabupaten Subang dalam bidang pengelolaan pasar sudah cukup baik. Hal itu bisa dilihat dari responden paling dominan yang memilih sangat setuju dan setuju yang lebih 
dominan, meskipun belum maksimal secara keseluruhan karena masih terdapat responden yang memilih kurang setuju dan tidak setuju meskipun dalam jumlah responden yang sangat sedikit.

\section{Rekapitulasi Skor Keseluruhan Variabel Implementasi Kebijakan}

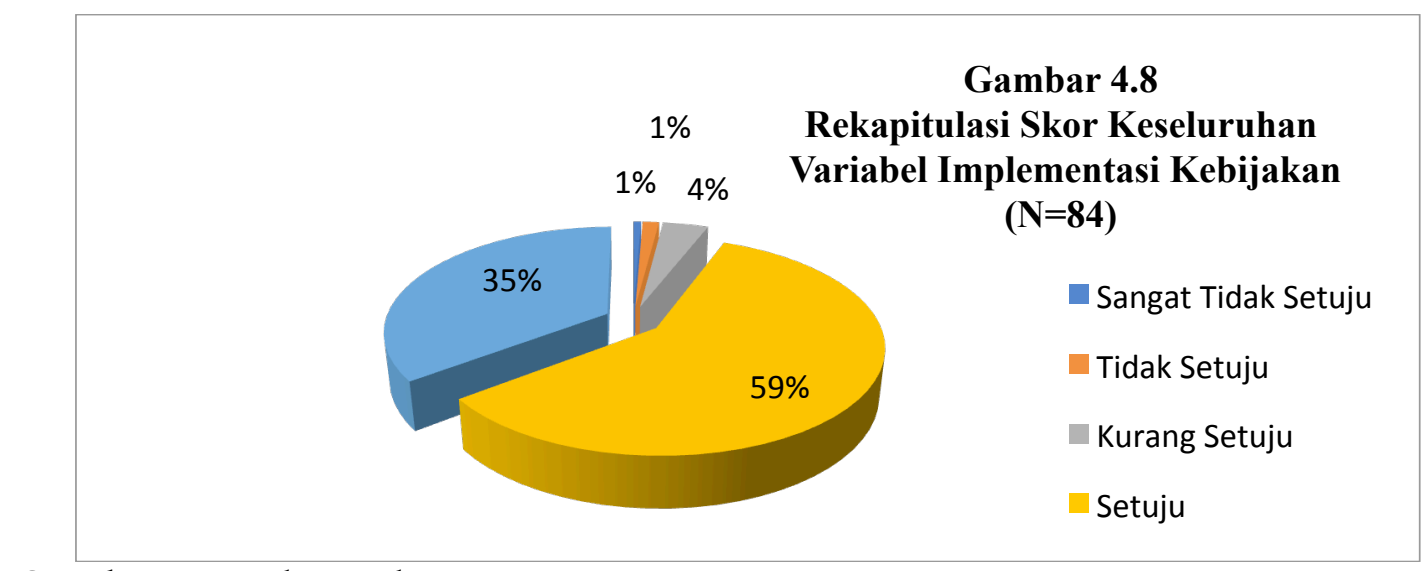

Sumber : Hasil Penelitian, 2016

Dari keseluruhan hasil penelitian yang penulis lakukan di Dinas Perindustrian, Perdagangan dan Pengelolaan Pasar Kabupaten Subang pada bidang pengelolaan pasar pada variabel implementasi kebijakan, penulis menyimpulkan bahwa implementasi kebijakan di Dinas Perindustrian, Perdagangan dan Pengelolaan Pasar Kabupaten Subang pada bidang pengelolaan pasar dalam hal penataan pasar dan pembinaan pedagang sudah cukup baik meskipun secara keseluruhan belum maksimal dan perlu peningkatan dalam keseluruhan dimensi dari variabel implementasi kebijakan tersebut. Hal ini dapat dilihat dari keseluruhan variabel implementasi kebijakan yakni responden lebih dominan memilih setuju dan masih ada responden yang memilih kurang setuju,tidak setuju bahkan sangat tidak setuju meskipun dalah jumlah presentase responden yang sedikit.

\section{Tanggapan Responden atas Variabel Efektivitas}

Dari hasil pembahasan pada uraian-uraian yang telah dikemukakan sebelumnya dapat diketahui bahwa dari implementasi kebijakan di Dinas Perindustrian, Perdagangan dan Pengelolaan Pasar Kabupaten Subang sudah cukup baik tingkat implementasinya meskipun belum maksimal secara keseluruhan. Sedangkan untuk mengetahui sejauh mana tingkat efektivitas, maka penulis memilih tolok ukur faktor-faktor efektivitas menurut Nugroho (2003:179) yakni sebagai berikut : Tepat Kebijakannya, Tepat Pelaksanaanya, Tepat Targetnya, dan Tepat Lingkungannya

Dari pendapat di atas terdapat 4 dimensi yang terbagi dalam 9 indikator pertanyaan untuk pengolahan data yang bertujuan untuk mengetahui frekuensi jawaban pilihan responden yang ditabulasi (terdapat pada lampiran) 


\section{Tanggapan Responden atas Dimensi Tepat Kebijakannya}

Untuk mengetahui tanggapan responden atas dimensi tepat kebijakannya, yang kemudian hasilnya ditabulasikan dalam bentuk pie chart yang dijelaskan sebagai berikut :

\section{Gambar 4.10}

Tepat Kebijakannya

$(\mathbf{n}=\mathbf{8 4})$

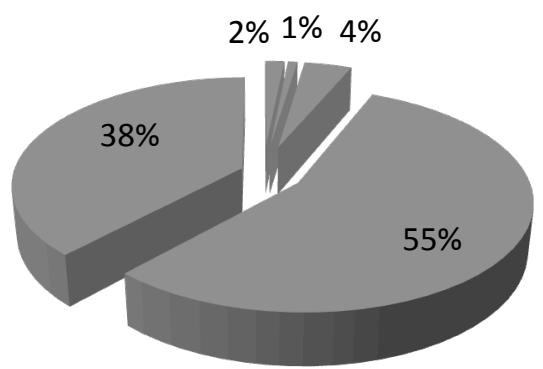

- Sangat Tidak Setuju

- Tidak Setuju

Kurang Setutu

Setuju

\section{Sumber : Hasil Penelitian, 2016}

Tepat kebijakannya merupakan salah satu dimensi penunjang untuk mencapai efektivitas yang baik, maka kebijakan yang tepat amatlah penting dan harus di perhatikan oleh Dinas Perindustrian, Perdagangan dan Pengelolaan Pasar Dari hasil penelitian di atas bahwa dimensi tepat kebijakannya bahwa responden lebih dominan menyatakan setuju dan sangat setuju. Hal ini menunjukan kebijakan di Dinas Perindustrian, Perdagangan dan Pengelolaan Pasar Kabupaten Subang pada Bidang pengelolaan pasar sudah cukup baik meskipun belum secara keseluruhan. Hal ini dikarenakan masih terdapat responden yang memilih kurang setuju, tidak setuju, dan sangat tidak setuju.

\section{Tanggapan Responden atas Dimensi Tepat Pelaksanaanya}

Untuk mengetahui tanggapan responden atas dimensi tepat pelaksanannya, yang kemudian hasilnya ditabulasikan dalam bentuk pie chart yang dijelaskan sebagai berikut :

Gambar 4.11

Tepat Pelaksananya

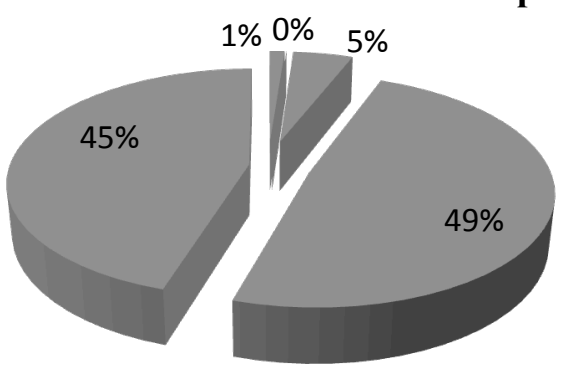

$(\mathrm{N}=\mathbf{8 4})$

$$
\begin{aligned}
& \text { Sangat Tidak Setuju } \\
& \text { Tidak Setuju } \\
& \text { Kurang Setutu } \\
& \text { Setuju } \\
& \text { Sangat Setuju }
\end{aligned}
$$

Sumber : Hasil Penelitian, 2016

Tepat pelaksanaannya merupakan salah satu dimensi penunjang untuk mencapai efektivitas yang baik, maka pelaksanaan yang tepat amatlah penting dan harus diperhatikan oleh Dinas Perindustrian, Perdagangan dan Pengelolaan Pasar . 
Dari hasil penelitian di atas bahwa dimensi tepat pelaksanaanya bahwa responden lebih dominan menyatakan setuju dan sangat setuju. Hal ini menunjukan pelaksanannya sudah tepat di Dinas Perindustrian, Perdagangan dan Pengelolaan Pasar Kabupaten Subang pada Bidang pengelolaan pasar sudah cukup baik meskipun belum secara keseluruhan itu dikarenakan masih terdapat responden yang memilih kurang setuju, dan sangat tidak setuju meskipun responden yang memilih dalam jumlah yang sedikit.

\section{Tanggapan Responden atas Dimensi Tepat Targetnya}

Untuk mengetahui tanggapan responden atas dimensi tepat targetnya, yang kemudian hasilnya ditabulasikan dalam bentuk pie chart yang dijelaskan sebagai berikut :

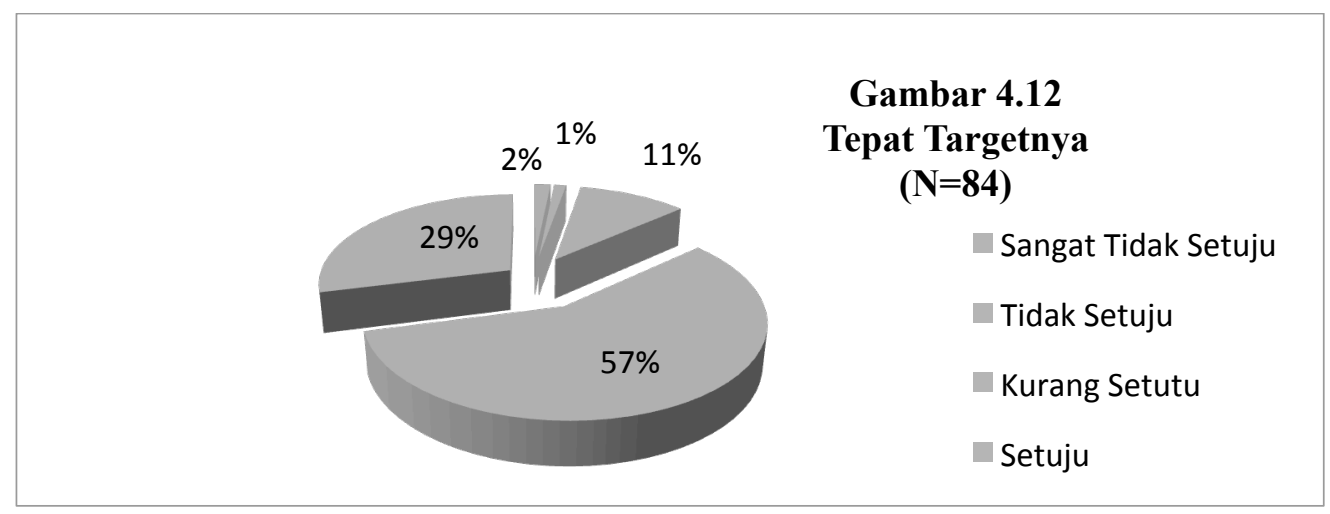

Sumber : Hasil Penelitian, 2016

Tepat targetnya dalam efektivitas merupakan salah satu dimensi penunjang untuk mencapai efektivitas pembinaan yang baik, maka tepat targetnya dalam kinerja amatlah penting dan harus di perhatikan oleh Dinas Perindustrian, Perdagangan dan Pengelolaan Pasar . Dari hasil penelitian di atas pada dimensi tepat targetnya bahwa responden lebih dominan menyatakan setuju dan sangat setuju. Hal ini menunjukan bahwa pencapaian target yang tepat dalam kinerja Dinas Perindustrian, Perdagangan dan Pengelolaan Pasar Kabupaten Subang pada Bidang Angkutan pengelolaan pasar sudah cukup baik meskipun belum secara keseluruhan itu dikarenakan masih terdapat responden yang memilih kurang setuju, tidak setuju, dan sangat tidak setuju meskipun responden yang memilih dalam jumlah yang sedikit.

\section{Tanggapan Responden atas Dimensi Tepat Lingkungannya}

Untuk mengetahui tanggapan responden atas dimensi tepat lingkungannya, yang kemudian hasilnya ditabulasikan dalam bentuk pie chart yang dijelaskan sebagai berikut : 


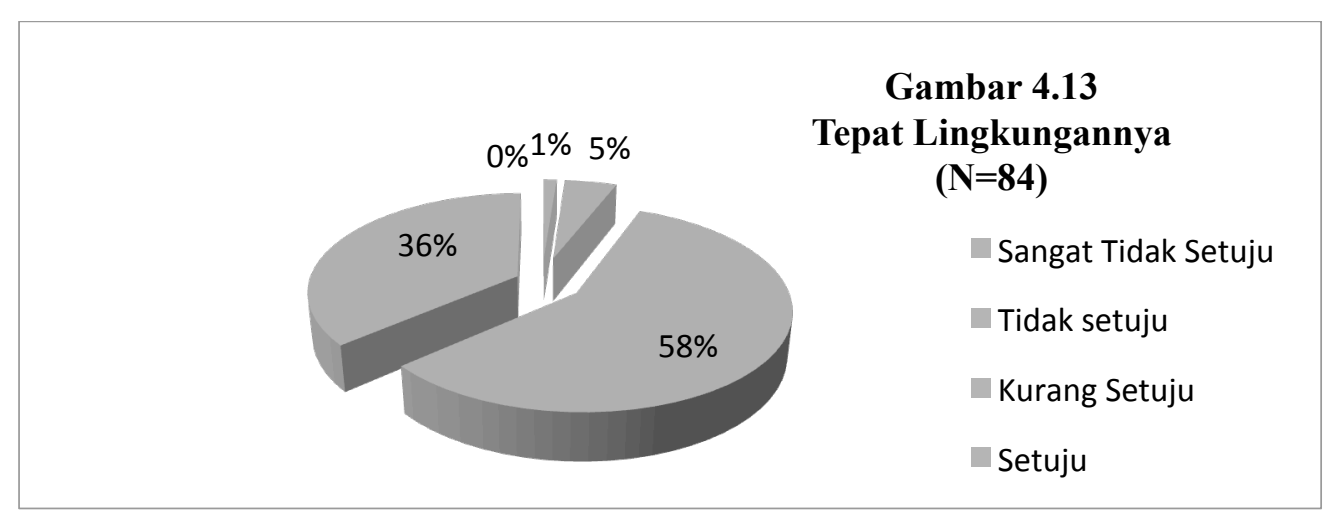

Sumber : Hasil Penelitian, 2013

Tepat lingkungannya dalam efektivitas pembinaan merupakan salah satu dimensi penunjang untuk mencapai kinerja yang baik, maka tepat lingkungannya dalam efektivitas amatlah penting dan harus di perhatikan oleh Dinas Perindustrian, Perdagangan dan Pengelolaan Pasar. Dari hasil penelitian di atas pada dimensi tepat lingkungannya bahwa responden lebih dominan menyatakan setuju dan sangat setuju. Hal ini menunjukan bahwa tepat lingkungan dalam efektivitas Dinas Perindustrian, Perdagangan dan Pengelolaan Pasar Kabupaten Subang pada Bidang pengelolaan pasar sudah cukup baik meskipun belum secara keseluruhan. Hal ini dikarenakan masih terdapat responden yang memilih kurang setuju, dan tidak setuju meskipun responden yang memilih dalam jumlah yang sedikit.

\section{Rekapitulasi Skor Keseluruhan Variabel Efektivitas}

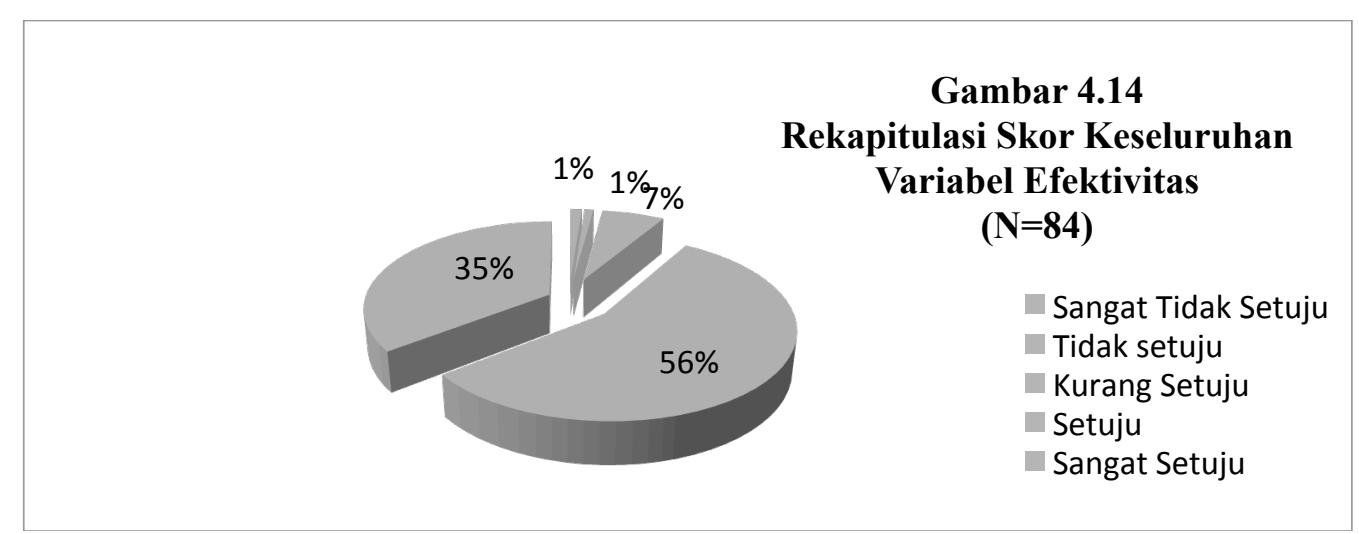

Sumber : Hasil Penelitian, 2016

Dari chart di atas dapat terlihat keseluruhan hasil penelitian yang penulis lakukan di Dinas Perindustrian, Perdagangan dan Pengelolaan Pasar pada bidang pengelolaan pasar pada variabel efektivitas, penulis menyimpulkan bahwa efektivitas pembinaan pedagang di Dinas Perindustrian, Perdagangan dan Pengelolaan Pasar Kabupaten Subang pada Bidang pengelolaan pasar dalam pembinaan pedagang sudah baik meskipun belum secara keseluruhan, masih ada beberapa faktor yang perlu peningkatan dalam keseluruhan dimensi dari variabel efektivitas tersebut. Hal ini dapat dilihat dari keseluruhan variabel efektivitas yakni, responden menjawab setuju dan sangat setuju lebih dominan, dan masih ada 
responden yang memilih kurang setuju, tidak setuju dan sangat tidak setuju meski dalam jumlah yang sedikit.

Dengan demikian dapat disimpulkan, bahwa efektivitas pembinaan pedang pada Dinas Perindustrian, Perdagangan dan Pengelolaan Pasar Kabupaten Subang pada bidang pengelolaan pasar dalam penataan pedang orang sudah baik meskipun belum maksimal.

Analisis Pengaruh Implementasi Kebijakan Penataan Pasar Tradisional dan TokoModern Terhadap Efektivitas Pembinaan Sektor Informal di Kabupaten Subang

Sebagai dasar penentuan tingkat hubungan antar variabel, Sugiyono (2009: 214) memberikan pedoman interpretasi koefisien korelasi sebagai berikut :

Tabel 2

Interpretasi Terhadap Koefisien Korelasi

\begin{tabular}{|c|c|}
\hline Interval Koefisien & Tingkat Hubungan \\
\hline $0,00 \leq \mathrm{r}<0,2$ & Sangat Rendah \\
$0,20 \leq \mathrm{r}<0,4$ & Rendah \\
$0,40 \leq \mathrm{r}<0,6$ & Sedang \\
$0,60 \leq \mathrm{r}<0,8$ & Kuat \\
$0,80 \leq \mathrm{r}<1,00$ & Sangat Kuat \\
\hline
\end{tabular}

Sumber : Sugiyono, $2009: 214$

Untuk melihat ada atau tidaknya hubungan antara implementasi kebijakan dengan efektivitas, maka sebelumnya telah diajukan hipotesis penelitian sebagai berikut :

“Terdapat Pengaruh Signifikan Antara Implementasi Kebijakan Penataan Pasar Tradisional dan Toko Modern Terhadap Efektivitas Pembinaan Sektor Informal di Kabupaten Subang". Dalam menghitung besarnya hubungan antar variabel, penulis menggunakan koefisien Pearson korelasi Product Moment dalam Sugiyono (2011 : 228) dengan rumus :

$$
\begin{gathered}
r=\frac{\mathrm{N}\left(\sum \mathrm{XY}\right)-\left(\sum \mathrm{X} \cdot \sum \mathrm{Y}\right)}{\sqrt{\left[\mathrm{N} \sum \mathrm{X}^{2}-\left(\sum \mathrm{X}\right)^{2}\right]\left[\mathrm{N} \sum \mathrm{Y}^{2}-\left(\sum \mathrm{Y}\right)^{2}\right.}} \\
84(7880914,8)-(3101,4.2541,083) \\
r=\frac{661996843-7880914,82}{\sqrt{\left[(84.9618681,96-(3101,4))^{2}\right]\left[(84.6457102,813-(2541,083))^{2}\right]}} \\
r=\frac{654115928}{\sqrt{[(203416,799][181887,136]}} \\
r=\frac{654115928}{\sqrt{36998898964)}} \\
r=\frac{170742,29}{98609,284}
\end{gathered}
$$


Dan berdasarkan hasil perhitungan dapat disimpulkan bahwa hubungan antar variabel Implementasi kebijakan dengan efektivitas adalah "sangat kuat" dengan nilai 0,888. Sebagaimana diungkapkan oleh Sugiyono (2009:214) nilai tersebut berada pada interval koefisien $0,80 \leq r<1,00$. Jadi terdapat hubungan yang sangat kuat antara implementasi kebijakan dan efetktivitas, utuk menguji signifikansi hubungan yaitu apakah hubungan yang ditemukan itu berlaku untuk seluruh populasi yang berjumlah 540 orang, maka perlu diuji Signifikansinya. Uji signifikansi korelasi product moment nilai $\mathrm{r}$ tabel untuk $\mathrm{n}=84$ dengan taraf kesalahan 5\% maka $r$ tabel $=0,213$ dan $r$ hitung $=0,888$. Ketentuan bila $r$ hitung lebih besar dari $\mathrm{r}$ tabel, maka H0 ditolak dan Ha diterima. Jadi kesimpulannya ada hubungan positif dan nilai koefisien korelasi antara Implementasi kebijakan dan efektivitas sebesar 0,888. Data dan koefisien yang diperoleh dalam sampel tersebut dapat digeneralisasikan pada populasi dimana sampel diambil atau data tersebut mencerminkan keadaan populasi/mewakili keseluruhan populasi.

Selanjutnya analisis dilaksanakan menggunakan bantu paket Statistics Programme For Social Science (SPSS) Version 16.0, dengan hasil sebagai berikut:

Tabel 3

Correlations

\begin{tabular}{|lc|r|r|}
\hline & & $\begin{array}{c}\text { variabel } \\
\mathrm{y}\end{array}$ & $\begin{array}{c}\text { variabel } \\
\mathrm{x}\end{array}$ \\
\hline $\begin{array}{c}\text { Pearson } \\
\text { Correlation }\end{array}$ & $\begin{array}{c}\text { variabel } \\
\mathrm{y} \\
\text { variabel } \\
\mathrm{x}\end{array}$ & 1.000 & .888 \\
& $\begin{array}{c}\text { variabel } \\
\mathrm{y} \\
\text { vig. (1-tailed) }\end{array}$ & & 1.000 \\
& $\begin{array}{c}\mathrm{x} \\
\text { variabel } \\
\mathrm{N}\end{array}$ & .000 & .000 \\
\hline & $\begin{array}{c}\mathrm{y} \\
\text { variabel } \\
\mathrm{x}\end{array}$ & 84 & 84 \\
& & 84 & 84 \\
\hline
\end{tabular}

Tabel korelasi menunjukan hubungan dua variabel, arah hubungan dan seberapa besar hubungan tersebut, kemudian berdasarkan koefisien korelasi didapat koefisien determinasi. Untuk mengetahui hubungan dapat dilakukan pengujian hipotesa :

Ho : $\quad=0$; tidak terdapat pengaruh antara variabel implementasi kebijakan penataan pasar tradisional dan toko modern terhadap variabel efektivitas pembinaan sektor informal di Kabupaten Subang. 
Ha : $\quad \neq 0$; terdapat pengaruh antara variabel implementasi kebijakan penataan pasar tradisional dan toko modern terhadap variabel efektivitas pembinaan sektor informal di Kabupaten Subang.

Dengan ketentuan: apabila probabilitas < 0,05 maka Ho ditolak ; jika probabilitas > 0,05 maka Ha diterima.

Dari signifikasi terlihat bahwa pada angka Sig (2) adalah 0,000 $<0,05$ sehingga Ho ditolak dan Ha diterima, artinya ada hubungan antara pengaruh implementasi kebijakan penataan pasar tradisional dan toko modern terhadap efektivitas pembinaan sektor informal. Hubungan antara pengaruh Implementasi kebijakan dengan efektivitas didapat $+0,888$ ini berarti arah korelasi positif atau makin tinggi pengaruh implementasi kebijakan maka efektvitas pembinaan sektor informal cenderung meningkat. Besar korelasi tersebut apabila dikonsultasikan pada pedoman interpretasi koefisien korelasi berarti pengaruh implementasi kebijakan berhubungan sangat kuat terhadap efektivitas pembinaan sektor informal.

Untuk mengetahui seberapa besar pengaruh Implementasi kebijakan penataan pasar tradisional dan toko modern terhadap Efektivitas pembinaan sektor informal dapat dilihat dengan menggunakan analisis regresi linear, dengan menggunakan bantuan paket Statistics Programme For Social Science (SPSS) Version 16.0, dengan hasil sebagai berikut :

Hasil analisis regresi didapatkan koefisien korelasi (R) sebesar 0,888 dengan koefisien determinasi (Rsquare) sebesar 0,788 atau 78,8\%

Tabel 4.

Model Summary

\begin{tabular}{|c|c|c|c|c|c|c|c|c|c|}
\hline \multirow[b]{2}{*}{ Model } & \multirow[b]{2}{*}{$\mathrm{R}$} & \multirow[b]{2}{*}{ R Square } & \multirow[b]{2}{*}{$\begin{array}{r}\text { Adjusted R } \\
\text { Square }\end{array}$} & \multirow{2}{*}{$\begin{array}{c}\text { Std. Error of } \\
\text { the } \\
\text { Estimat } \\
\mathrm{e}\end{array}$} & \multicolumn{5}{|c|}{ Change Statistics } \\
\hline & & & & & $\begin{array}{c}\text { R Square } \\
\text { Chang } \\
\mathrm{e}\end{array}$ & F Change & df1 & df2 & $\begin{array}{l}\text { Sig. F } \\
\text { Chan } \\
\text { ge }\end{array}$ \\
\hline 1 & $.888^{a}$ & .788 & .785 & 2.36634 & .788 & 304.689 & 1 & 82 & .000 \\
\hline
\end{tabular}

a. Predictors: (Constant),

variabel $x$

Nilai Rsquare (koefisien korelasi) menyatakan persentase variabilitas variabel efektivitas yang dapat dijelaskan oleh Implementasi kebijakan Rsquare $=0,788$ atau menunjukan bahwa 78,8 \% variabel efektivitas yang dapat dijelaskan oleh Implementasi kebijakan, sisanya dipengaruhi oleh faktor lain yang tidak diteliti oleh penulis.

Artinya bahwa dari 78,8\% pengaruh Implementasi kebijakan penataan pasar tradisional dan toko modern terhadap efektivitas pembinaan sektor informal di Kabupaten Subang, masing-masing variabel Implementasi kebijakan memberikan sumbangan yang cukup besar terhadap Efektivitas pembinaan sektor informal di Kabupaten Subang

\section{Analisis Regresi}

Adapun untuk koefisien-koefisien regresinya secara parsial dapat dilihat pada tabel berikut ini : 
Tabel 5

\section{Coefficients ${ }^{\mathrm{a}}$}

\begin{tabular}{|c|c|c|c|c|c|c|c|c|c|c|c|c|}
\hline \multirow[b]{2}{*}{ Model } & \multicolumn{2}{|c|}{$\begin{array}{r}\text { Unstandardized } \\
\text { Coefficients }\end{array}$} & \multirow{2}{*}{$\begin{array}{c}\begin{array}{c}\text { Standardized } \\
\text { Coefficie } \\
\text { nts }\end{array} \\
\\
\\
\text { Beta } \\
\end{array}$} & \multirow[b]{2}{*}{$\mathrm{T}$} & \multirow[b]{2}{*}{ Sig. } & \multicolumn{2}{|c|}{$\begin{array}{l}\text { 95\% Confidence } \\
\text { Interval for B }\end{array}$} & \multicolumn{3}{|c|}{ Correlations } & \multicolumn{2}{|c|}{$\begin{array}{l}\text { Collinearity } \\
\text { Statistics }\end{array}$} \\
\hline & B & $\begin{array}{c}\text { Std. } \\
\text { Err } \\
\text { or }\end{array}$ & & & & $\begin{array}{c}\text { Lower } \\
\text { Bou } \\
\text { nd }\end{array}$ & $\begin{array}{c}\text { Upper } \\
\text { Boun } \\
d\end{array}$ & $\begin{array}{c}\text { or } \\
\text { de } \\
\mathrm{r}\end{array}$ & Partial & Part & Tolerance & VIF \\
\hline 1 (Constant) & -.739 & 1.794 & & -.412 & .682 & -4.308 & 2.830 & & & & & \\
\hline variabel x & .839 & .048 & .888 & 17.455 & .000 & .744 & .935 & .888 & .888 & .888 & 1.000 & 1.000 \\
\hline
\end{tabular}

a. Dependent

Variable: variabel

y

Dari tabel 4.10 dapat dilihat bahwa koefisien korelasi product moment (zero order correlation) pada variabel Implementasi kebijakan sebesar 0,888 dan koefisien partial correlation adalah 0,888 .

Maka dari penjelasan pada tabel 4.10 diperoleh persamaan regresi antara implementasi kebijakan dan efektivitas adalah sebagai berikut :

$\mathrm{Y}=\mathrm{a} \pm \mathrm{bx}$

$Y=-0,739+0,839 X$

Berdasarkan persamaan regresi yang terbentuk menjelaskan bahwa konstanta memiliki nilai negatif dan koefisien variabel-variabel independen memiliki nilai positif. Hal ini menandakan bahwa persamaan regresi tersebut memiliki hubungan dari nilai negative menuju positif dan menunjukan adanya pengaruh signifikan, yang berarti efektivitas akan meningkat seiring dengan meningkatnya pengaruh Implementasi kebijakan.

Persamaan regresi yang telah ditemukan dapat digunakan untuk melakukan prediksi (ramalan) bagaimana individu dalam variabel dependen akan terjadi bila individu dalam variabel independent ditetapkan. Misalnya nilai Implementasi kebijakan $=40$, maka nilai rata-rata efektivitas adalah :

$\mathrm{Y}=-0.739+0,839.40$

$\mathrm{Y}=32,821$

Jadi diperkirakan nilai rata-rata efektivitas sebesar 32,821. Dari persamaan regresi tersebut dapat diartikan bahwa, bila nilai implementasi kebijakan bertambah 1, maka nilai rata -rata efektivitas akan bertambah 0,839 atau setiap nilai implementasi kebijakan bertambah 10 maka nilai rata-rata efektivitas akan bertambah 8,39.

Sedangkan untuk menguji signifikasi korelasi, dapat dihitung menggunakan rumus uji $\mathrm{F}$ atau uji ANOVA, yang lebih jelasnya dapat dilihat pada tabel 4.11 berikut 
Tabel 6

\begin{tabular}{|c|c|c|c|c|c|c|}
\hline \multicolumn{7}{|c|}{$\mathbf{A N O V A}^{\mathbf{b}}$} \\
\hline & & Sum of Squares & Df & Mean Square & $\mathrm{F}$ & Sig. \\
\hline \multirow[t]{3}{*}{1} & Regression & 1706.127 & 1 & 1706.127 & 304.689 & $.000^{a}$ \\
\hline & Residual & 459.164 & 82 & 5.600 & & \\
\hline & Total & 2165.291 & 83 & & & \\
\hline
\end{tabular}

a. Predictors: (Constant), variabel $x$

b. Dependent Variable: variabel y

Melalui uji F atau Uji ANOVA, dapat diketahui nilai F hitung sebesar 304,689 dengan tingkat signifikansi 0,000. Hasil uji $\mathrm{F}$ menunjukan bahwa nilai probabilitas 0,000 jauh lebih kecil dibandingkan dengan 0,05 atau $(0,000<0,005)$. Dengan demikian dapat disimpulkan bahwa model regresi yang dihasilkan dapat digunakan untuk memprediksikan implementasi kebijakan .

\section{Variabel Implementasi Kebijakan}

Dalam penelitian ini, dimensi komunikasi dari Dinas Perindustrian, Perdagangan dan Pengelolaan Pasar sudah bersinergi tinggi dalam memenuhi kewajibannya kepada para pedagang di pasar tradisional yang mencapai $45 \%$ memilih setuju dalam penilaian positif atas komunikasi yang diberikan petugas dalam menyelesaikan pekerjaannya. Bahkan, penilaian positif ini juga didukung oleh sangat tingginya penilaian pedagang memilih sangat setuju mencapai $45 \%$ atas kesamaan komunikasi yang disampaikam petugas dalam menyelesaikan pekerjaannya. Kesamaan komunikasi yang disampaikan ini dikarenakan bahwa komunikasi menjadi upaya untuk mendorong, mengarahkan, dan memilih perilaku menuju tindakan atau tujuan tertentu.

Dalam penelitian ini, dimensi sumberdaya pada Dinas Perindustrian, Perdagangan dan Pengelolaan Pasar sudah memenuhi kewajibannya kepada para pedagang yang mencapai $59 \%$ memilih setuju dalam penilaian positif atas sumberdaya yang ditunjukan petugas dalam menyelesaikan pekerjaannya. Bahkan, penilaian positif ini juga didukung oleh sangat tingginya penilaian pedagang memilih sangat setuju mencapai $35 \%$ atas sumberdaya yang dimiliki petugas dalam menyelesaikan pekerjaannya. Tingginya dimensi sumberdaya ini dikarenakan bahwa sumberdaya merupakan faktor yang berpengarus secara langsung terhadap keefektifan pelaksanaan kebijakan menjadi dan salah satu upaya dalam memberikan respon yang konsisten terhadap situasi atau informasi.

Dalam penelitian ini, dimensi disposisi dari Dinas Perindustrian, Perdagangan dan Pengelolaan Pasar sudah bersinergi tinggi dalam memenuhi kewajibannya kepada para pedagang yang mencapai $61 \%$ memilih setuju dalam penilaian positif atas disposisi yang diberikan petugas dalam menyelesaikan pekerjaannya. Bahkan, penilaian positif ini juga didukung oleh sangat tingginya pedagang memilih sangat setuju mencapai 33\% atas disposisi yang diberikan petugas dalam menyelesaikan pekerjaannya. Tingginya dimensi disposisi ini 
dikarenakan bahwa disposisi menjadi upaya menambah rasa percaya diri agar dapat efektif hampir dalam setiap situasi dan konsisi apapun.

Dalam penelitian ini, dimensi struktur birokrasi Dinas Perindustrian, Perdagangan dan Pengelolaan Pasar sudah bersinergi tinggi dalam memenuhi kewajibannya pedagang yang mencapai $61 \%$ memilih setuju dalam penilaian positif atas struktur birokrasi yang diberikan petugas dalam menyelesaikan pekerjaannya. Bahkan, penilaian positif ini juga didukung oleh sangat tingginya pedagang memilih sangat setuju mencapai 36\% atas struktur birokrasi yang diberikan petugas dalam menyelesaikan pekerjaannya. Tingginya dimensi struktur birorasi ini dikarenakan bahwa struktur birokrasi terdapat suatu standart operating procedures (SOP) yang mengatur tata aliran pekerjaan dan pelaksanaan program atau prosedurprosedur rutin yang mengatur mekanisme kerja proses pelaksanaan kebijakan.

\section{Variabel Efektivitas}

Dalam penelitian ini, dimensi tepat kebijakannya pada Dinas Perindustrian, Perdagangan dan Pengelolaan Pasar sudah bersinergi tinggi dalam memenuhi kewajibannya kepada pedagang dalam penataan pasar dan pembinaan yang mencapai 55\% memilih setuju dalam penilaian positif atas tepat kebijakannya yang diberikan petugas dalam menyelesaikan pekerjaannya. Bahkan, penilaian positif ini juga didukung oleh sangat tingginya penilaian pedagang memilih sangat setuju mencapai $38 \%$ atas tepat kebijakannya yang diberikan petugas dalam menyelesaikan pekerjaannya. Tingginya dimensi tepat kebijakannya ini dikarenakan bahwa tepat kebijakan menjadi upaya untuk meminimalisir tingkat kesalahan,.

Dalam penelitian ini, dimensi tepat pelaksanannya pada Dinas Perindustrian, Perdagangan dan Pengelolaan Pasar sudah bersinergi tinggi dalam memenuhi kewajibannya kepada pedagang di pasar tradisional Kabupaten Subang dalam penataan dan pembinaan yang mencapai $49 \%$ memilih setuju dalam penilaian positif atas tepat pelaksanaanya yang diberikan petugas dalam menyelesaikan pekerjaannya. Bahkan, penilaian positif ini juga didukung oleh sangat tingginya penilaian pedagang memilih sangat setuju mencapai $45 \%$ atas tepat pelaksanaanya yang diberikan petugas dalam menyelesaikan pekerjaannya. Tingginya dimensi tepat pelaksananya ini dikarenakan bahwa kuantiitas kinerja menjadi upaya untuk tujuan agar jumlah pekerjaan yang dihasilkan sudah sesuai harapan.

Dalam penelitian ini, dimensi tepat targetnya dalam bekerja dari petugas pada Dinas Perindustrian, Perdagangan dan Pengelolaan Pasar sudah bersinergi tinggi dalam memenuhi kewajibannya kepada pedagang dalam penataan dan pembinaan yang mencapai $57 \%$ memilih setuju dalam penilaian positif atas penggunaan waktu dalam kinerja yang diberikan petugas dalam menyelesaikan pekerjaannya. Bahkan, penilaian positif ini juga didukung oleh sangat tingginya penilaian pedagang memilih sangat setuju mencapai $29 \%$ atas tepat targetnya dalam kerja yang diberikan petugas dalam menyelesaikan pekerjaannya. Tingginya dimensi tepat targetnya dalam kerja ini dikarenakan bahwa ketepatan target menjadi upaya untuk menciptakan waktu kerja yang efektif.

Dalam penelitian ini, dimensi tepat lingkungannya pada Dinas Perindustrian, Perdagangan dan Pengelolaan Pasar sudah bersinergi tinggi dalam memenuhi kewajibannya kepada pedagang dalam penatan dan pembinaan yang mencapai $58 \%$ 
memilih setuju dalam penilaian positif atas tepat lingkungannya yang ditunjukan petugas terhadap pedagang dalam menyelesaikan pekerjaannya. Bahkan, penilaian positif ini juga didukung oleh sangat tingginya penilaian pedagang memilih sangat setuju mencapai $36 \%$ atas atas tepat lingkungannya yang ditunjukan petugas terhadap pedagang dalam menyelesaikan pekerjaannya. Tingginya dimensi tepat lingkungannya ini dikarenakan bahwa ketepatan lingkungan menjadi upaya untuk menjalin kerjasama dengan pedagang dalam mewujudkan pelayanan menjadi lebih baik.

\section{Kesimpulan}

Hasil analisis data menunjukan bahwa implementasi kebijakan penataan pasar tradisional dan toko modern mempengaruhi efektivitas pembinaan sektor informal di Kabupaten Subang. Mengenai besarnya pengaruh implementasi kebijakan penataan pasar tradisional dan toko modern terhadap efektivitas pembinaan sektor informal di Kabupaten Subang, dapat ditarik kesimpulan sebagai berikut:

Berdasarkan penelitian yang telah penulis lakukan bahwa pada dasarnya implementasi kebijakan penataan pasar tradisional dan toko modern di Kabupaten Subang sudah cukup baik meskipun belum maksimal. Hal ini berdasarkan pada pengujian terhadap 4 dimensi yang terbagi menjadi 11 indikator pertanyaatan dalam kuesioner dan disebarkan kepada responden. Dari hasil deskriptif data penelitian dapat dikemukakan tanggapan responden terhadap pernyataan-pernyataan yang terdapat dalam kuesioner yaitu disimpulkan bahwa secara umum implementasi kebijakan penataan pasar tradisional dan toko modern di Kabupaten Subang sudah cukup baik meskipun belum maksimal secara keseluruhan. Hal ini ditunjukan oleh hasil jawaban dari responden yang lebih dominan menjawab setuju dan sangat setuju meskipun masih ada responden yang memilih kurang setuju ,tidak setuju, dan sangat tidak setuju meskipun dalam jumlah yang sedikit. Artinya bahwa implementasi kebijakan penataan pasar tradisional dan toko modern di Kabupaten Subang harus lebih di tingkatkan.

Berdasarkan variabel efektivitas pembinaan sektor informal yang terdiri dari 4 dimensi yang terbagi dari 9 indikator pertanyaan dalam kuesioner didapatkan data bahwa tingkat efektivitas pembinaan sektor informal di Kabupaten Subang sudah cukup baik meskipun belum maksimal secara keseluruhan itu terlihat dari hasil penelitian yang telah dilakukan dan diperoleh bahwa responden lebih dominan menjawab setuju dan sangat setuju meskipun masih ada responden yang menjawab kurang setuju ,tidak setuju, dan sangat tidak setuju meskipun dalam jumlah yang kecil. Artinya bahwa efektivitas pembinaan sektor informal di Kabupaten Subang harus lebih di tingkatkan.

Berdasarkan hasil penelitian diperoleh hasil analisi regresi dengan koefisien korelasi (R) sebesar 0.888 dan koefisien determinasi (Rsquare) sebesar 0,788 atau $78,8 \%$. Nilai Rsquare (koefisien determinasi) menyatakan persentase variabilitas variabel efektivitas yang dapat dijelaskan oleh variabel implementasi kebijakan Rsquare $=0,788$ atau menunjukan bahwa $78.8 \%$ variabel efektivitas yang dapat dijelaskan oleh implementasi kebijakan, sisanya dipengaruhi oleh faktor lain yang 
tidak diteliti oleh penulis. Artinya bahwa dari 78,8\% pengaruh implementasi kebijakan penataan pasar tradisional dan toko modern terhadap efektivitas pembinaan sektor informal di Kabupaten Subang, masing-masing variabel implementasi kebijakan memberikan sumbangan yang cukup besar terhadap efektivititas pembinaan sektor informal di Kabupaten Subang. Tingkat implementasi kebijkan dan efektivitas pembinaan sektor informal di Kabupaten Subang berada pada kategori kuat dengan nilai 0,888 nilai tersebut berada pada interval koefisien $0,60 \leq \mathrm{r}<0,8$, jadi terdapat hubungan yang kuat antara implementasi kebijakan dan efektivitas pembinaan sektor informal . Implementasi kebijakan mempunyai pengaruh positif terhadap efektivitas pembinaan sektor informal di Kabupaten subang. Terlihat pada $Y=-0,739+0,839$ X sehingga makin tinggi tingkat implementasi kebijakan akan semakin tinggi tingkat efektivitas pembinaan sektor informal di Kabupaten Subang.

\section{Referensi}

Ahmad Safrizal Yafie, Suharyono, Yusri Abdillah, (2016), Pengaruh Kualitas Produk atau Kualitas Jasa terhadap Kepuasan Pelanggan, Jurnal Administrasi Bisnis Vol. 35 No. 2

Budi Winarno, 1989 Teori Kebijakan Publik Pusat Antara Universitas Studi Sosial, Universitas Gaja mada, Yogyakarta

Fandy Tjiptono, (2014), Pemasaran Jasa, Yogyakarta : Penerbit ANDI

Fandy Tjiptono \& Gregorius Chandra, (2011), Service, Quality \& Statisfaction, edisi 3. Yogyakarta: Penerbit ANDI

Fadli Setia Hermanto (2012). "Pengaruh Koordinasi Dan Implementasi Kebijakan Terhadap Efektivitas Kerja Pegawai Pada Dinas Perindustrian Perdagangan Pengelolaan Pasar Kabupaten Subang".

Ghazali Imam 2014. Structural Equation Modeling Metode Alternatif dengan Partial Least Squarea (PLS). Universitas Diponogoro:Semarang

Malayu S.P Hasibuan, (2011), Manajemen: Dasar, Pengertian, dan Masalah, Bumi Aksara, Jakarta

Philip Kotler dan Kevin Lane Keller, (2009), Manajemen Pemasaran jilid I, edisi ketiga belas, Jakarta : Erlangga

Sugiyono, (2014), Metode Penelitian Bisnis, Alfabeta, Bandung

Sugiyono, (2012), Statistik Untuk Metode Penelitian Bisnis, Edisi 10. CV. Alfabeta, Bandung

Sugiyono, 2009 , Metode Penelitian Administrasi. Alfabeta: Bandung.

Sugiyono, 2010 , Statistik untuk Penelitian. Alfabeta: Bandung.

Wahab, Solichin Abdul. 2004. Analisis Kebijakan . dari Formulasi ke Implementasi

Kebijaksanaan Negara, Sinar Grafika, Jakarta 